\title{
Everything you ever wanted to know (or didn't know you wanted to know) about community compost!
}

\author{
Review by Malory Foster, University of Florida/Institute \\ of Food and Agricultural Sciences (IFAS) Extension*
}

Review of Community-Scale Composting Systems: A Comprehensive Practical Guide for Closing the Food System Loop and Solving Our Waste Crisis, by James McSweeney. (2019). Chelsea Green Publishing. Available in hardcover; 464 pages. Publisher's website: https://www.chelseagreen.com/product/community-

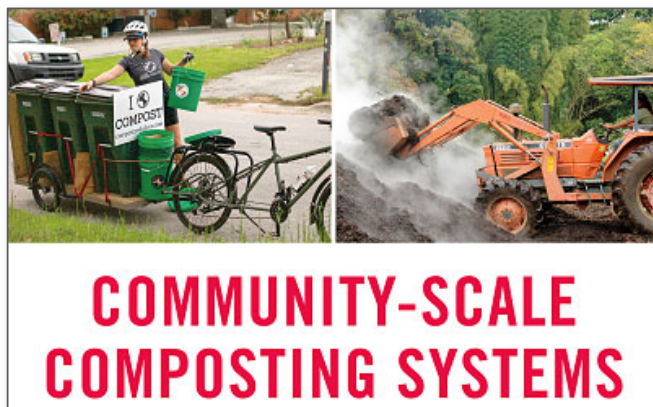

A Comprehensive Practical Guide for Closing the Food System Loop and Solving Our Waste Crisis

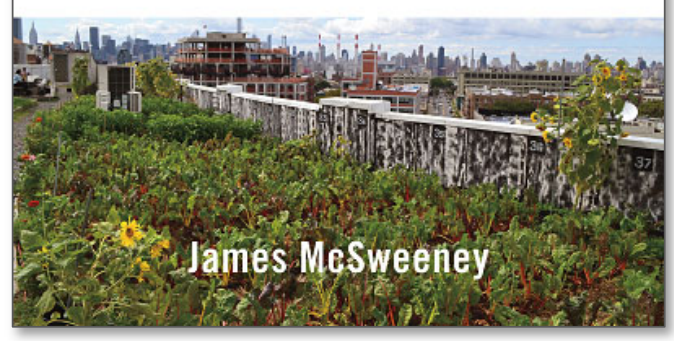
scale-composting-systems/

Citation: Foster, M. (2020). Everything you ever wanted to know (or didn't know you wanted to know) about community compost! [Book review]. Journal of Agriculture, Food Systems, and Community Development, 9(3), 317-319. https://doi.org/10.5304/jafscd.2020.093.003

Copyright (C) 2020 by the Author. Published by the Lyson Center for Civic Agriculture and Food Systems. Open access under CC-BY license.

W hat once may have been an underground movement to save organic materials from the waste stream, community composting is now celebrated and further empowered by James

* Malory Foster is a regional food systems specialist for the University of Florida/Institute of Food and Agricultural Sciences (IFAS) Extension Family Nutrition Program (the SNAP-Ed implementation agency in Florida). Her policy, systems, and environmental change work supports a diverse group of school and community gardeners, urban agriculture practitioners and advocates, and community composters. She supports a small community compost hub at her office, with elementary school kids managing the compost. She can be reached at University of Florida IFAS Extension; 12520

Ulmerton Road; Largo, FL 33774 USA; maloryrfoster@ufl.edu
McSweeney's technical guide Community-Scale Composting Systems: A Comprehensive Practical Guide for Closing the Food Systems Loop and Solving Our W aste Crisis. The book meticulously unpacks this major challenge facing the food system in the U.S.nothing short of a food waste crisis - and how to scale up in order to solve it. From the neighborly grassroots level to the budding entrepreneur, this tome feeds the budding "rotstar" on every scalefrom backyard composting to organic waste hauling. There's just something about composting for everyone. As McSweeney notes in the introduction, "Composting calls, it speaks from the beyond, drawing in believers. ... A large number maintain a deep belief in composting as part of a holistic way 
of life" (p. 5). His new book is a well-researched, intricate foray into the world of community composting.

In looking at creating holistic local food systems, food production is no easy task; however, growing food is often not the bottleneck. For locales working with sandy or clay soils or in urban corridors, closing the nutrient cycle is a real challenge-as well as an opportunity for sustainable soil remediation, increased organic matter in soil, and decreased landfill volume (Magdoff \& van Es, 2010). Expanding on the more established movement for backyard composting, community composting adds a social element, enterprise, and capacity-building to the growing practice of food scrap recycling. McSweeney outlines the $10 \mathrm{com}$ mon models of community composting and goes into great detail describing the management of each type.

This book is for anyone who is venturing into the world of composting entrepreneurship or organized community composting. McSweeney's attention to detail in walking out the steps for various scales of community compost makes this book a great reference for someone who is inspired to start a community composting business. While full of information and serving as a technical guide, McSweeney leads the reader through how to use the book, all the while painting a systems perspective. This 450-page volume is a reference for all scales of community composters, from backyard collectors to large scale compost entrepreneurs. Because of the breadth covered, not all the information included is relevant to everyone's dream compost project, but the broad scope will help readers assess their resources and determine their niche. The book is an excellent reference for those in the planning stage of a composting project.

From a whole systems perspective, McSweeney begins by explaining the community composting world from food scraps generation, to hauling, to organics recycling, to end compost users. He endorses the term "food scraps" as the industry term rather than "food waste," as is commonly used, to "begin transitioning from a waste paradigm to a resource paradigm" (p. 5). To achieve widespread implementation, community composting needs a variety of scales, which the author explores particu- larly for organics recycling, including on-farm, community gardens, schools and institutions, worker cooperatives, demonstration and training sites, and food scrap collection services. The core steps remain the same: compost is generated, collected, composted, and applied for end use.

McSweeney discusses compost recipes and addresses the critical areas of compost management: aeration, agitation, containment, and reaching optimal temperatures through several phases of finishing compost at various scales. These are the keys to creating safe compost. Chapter four dives into more detail on ingredients, "feedstocks," for compost recipes. An issue in some communities is the concern that composters inadvertently may produce methane because they do not adequately aerate piles or use enough carbon. The resulting "slime pit" becomes anaerobic and can produce methane. As it is presented in Drawdown by Paul Hawken, composting can be a powerful tool to sequester carbon instead of producing greenhouse gases. The focus of Community-Scale Composting Systems' recipe chapter is to explore appropriate compost recipes and procedures for a successful business and a high-quality product; however, quality compost also ensures the best results for climate change mitigation strategies. This chapter will help composters balance and blend locally available feedstocks, including considerations related to the carbon-to-nitrogen ratio and moisture, through more advanced considerations like bulk density, porosity, available carbon, $\mathrm{pH}$, salts, organic matter, feedstock age, and the many qualities of various feedstocks in recipe development.

McSweeney presents an exciting although theoretical framework for carbon-negative food products by substituting conventional feed with food scraps, but acknowledges that more research is necessary on this topic. A chapter on integrating livestock and composting is especially helpful for those compost operators who are interested in increasing agrobiodiversity and on-farm ecosystems services where the genetic diversity of crops and livestock improves overall farm efficiency (Kremen \& Miles, 2012). As a steward of backyard poultry, I was very curious about how to reduce the need for purchasing outside food sources for my hens. Included in the "Composting with Animals" chapter 
is a sidebar by Tom Gilbert of Black Dirt Farm on "feeding community food scraps to laying hens in an active composting system." This section provided good news to those hoping to decrease their laying hen feed costs as well as diversify their hens' feed and create a nutritionally superior diet "by mimicking the ecological systems of a forest floor (a decomposer system)" (p. 298).

As throughout the book, McSweeney outlines various scales of collecting and hauling compost, from bike transport to multistream collection. Bike-powered composting is a growing trend, so much so that the Institute for Local Self Reliance recently published a report in which they interviewed 17 bike-powered compost companies in 10 states on strategies for entrepreneurs interested in starting this type of business. Qualities that made a bike transport business more viable were denser pick-up areas, familiarity with the neighborhoods, and understanding local trash collection and tipping fees (Streeter \& Platt, 2017). Community-Scale Composting Systems describes, impressively, that bike haulers can move up to ten tons per load (p. 14)!

This book is an excellent resource for libraries, community hubs, and learning spaces. It provides detailed information on composter operations, management, and determining end markets for entrepreneurs and larger-scale community composters. For more casual readers, like the backyard composter or very small-scale community composter, it would be a useful reference to check out from a local library or borrow from a friend. Community-Scale Composting Systems is a thorough reference on the many scales and designs for community compost operations and brings the community composting movement to the next level.

\section{References}

Hawken, P. (Ed.). (2017). Drawdown: The most comprehensive plan ever proposed to reverse global warming. New York: Penguin.

Kremen, C., \& Miles, A. (2012). Ecosystem services in biologically diversified versus conventional farming systems:

Benefits, externalities, and trade-offs. Ecology and Society, 17(4), Art. 40. http://dx.doi.org/10.5751/ES-05035-170440

Magdoff, F., \& van Es, H. (2010). Building soils for better crops (3 $3^{\text {rd }}$ ed.). College Park, Maryland: Sustainable Agriculture Research and Education (SARE).

Streeter, V., \& Platt, B. (2017). Bike powered food scraps collection. BioCycle, 58(1), 46. Retrieved from https://www.biocycle.net/2017/01/12/bike-powered-food-scraps-collection/ 